Jurnal Olahraga \& Kesehatan Indonesia

Volume 1 Nomor 2 (2021)

E-ISSN: 2747-061X

available online at https://jurnal.stokbinaguna.ac.id/index.php/jok

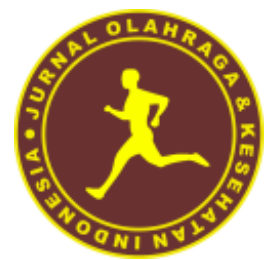

\title{
KONTRIBUSI LATIHAN KNEE TUCK JUMP DAN WALL PUSH UP TERHADAP JUMP SMASH BULU TANGKIS
}

\author{
Muhammad Hafiz Ham Hasibuan ${ }^{1}{ }^{*}$, Muhammad Nustan Hasibuan ${ }^{2}$ \\ ${ }^{12}$ Universitas Negeri Medan, Sumatera Utara, Indonesia, 20221 \\ *Coressponding Author: mhafizhamhasibuan@gmail.com
}

\begin{abstract}
Keterangan
Rekam Jejak:

Received, April 2021

Revised, Mei 2021

Accepted, Juni 2021

Kata Kunci:

Knee Tuck Jump, Wall Push

Up, Jump Smash, Bulu Tangkis

Masih rendahnya hasil jump smash pada permainan bulu tangkis menjadikan pencapaian prestasi atlet bulu tangkis klub PB Angsapura Medan masih minim dibandingkan dengan klub lainnya. Penelitian ini bertujuan untuk menemukan kontribusi dari latihan Knee Tuck Jump dan Latihan Wall Push Up terhadap hasil jump smash pada cabang olahraga bulu tangkis klub PB Angsapura Medan Tahun 2020. Metode penelitian yang digunakan dalam penelitian ini adalah metode eksperimen, sampel yang digunakan dalam penelitian ini adalah berjumlah 8 (delapan) orang. Penelitian dilaksanakan pada tanggal 16 November 2020, perhitungan statistik yang digunakan dalam penelitian ini adalah;uji persyaratan Analisis, uji Normalitas, dan uji Keberartian Regresi. Analisis pertama yaitu latihan knee tuck jump memberikan kontribusi yang signifikan terhadap peningkatan hasil jump smash pada cabang olahraga bulu tangkis klub PB Angsapura Medan Tahun 2020. Berdasarkan hasil perhitungan Fhitung $=13,36$ dan Ftabel $(0.05 ; 1 / 6)=2,36$, sehingga Fhitung > Ftabel dengan kontribusi sebesar $68,89 \%$. Analisis hipotesis kedua yaitu, latihan wall push up memberikan kontribusi yang signifikan terhadap peningkatan hasil jump smash pada cabang olahraga bulu tangkis klub PB Angsapura Medan Tahun 2020, Berdasarkan hasil perhitungan $\mathrm{F}_{\text {hitung }}=11,85$ dan $\mathrm{F}_{\text {tabel }(0.05 ; 1 / 6)}=2,36$, sehingga $\mathrm{F}_{\text {hitung }}>\mathrm{F}_{\text {tabel }}$ dengan kontribusi sebesar 67,24\%.Analisis hipotesis ketiga yaitu, latihan knee tuck jump dan wall push up memberikan kontribusi yang signifikan secara bersama-sama terhadap peningkatan jump smash pada cabang olahraga bulu tangkis klub PB Angsapura Medan Tahun 2020. Berdasarkan perhitungan Fhitung $>$ Ftabel $=$ Ho ditolak dengan kontribusi 74\%. Dari pengujian hipotesis dapat disimpulkan bahwa terdapat kontribusi yang signifikan dari latihan knee tuck jump dan latihan wall push up terhadap peningkatan hasil jump smash pada cabang olahraga bulu tangkis klub PB Angsapura Medan Tahun 2020.
\end{abstract}

Copyright (C) 2020

Jurnal Olahraga \& Kesehatan Indonesia 


\section{PENDAHULUAN}

Menurut Tony Grice (2007:1) bulutangkis ialah suatu permainan yang tidak dipantulkan dan harus dimainkan di udara sehingga permainan ini merupakan permainan cepat yang membutuhkan gerak reflek yang baik dan tingkat kebugaran yang tinggi. Pemain bulutangkis juga dapat mengambil keuntungan dari permainan ini dari segi sosial, hiburan dan mental. Olahraga bulutangkis dapat di lakukan dimana saja dan kapan pun, dilihat dari pertandingan pun telah dilaksanakan mulai dari pedesan maupun perkotaan. Hal ini membuktikan bahwa betapa olahraga bulutangkis mengalami perkembangan sangat pesat dari waktu ke waktu. Menurut Herman Subarjah (2004:3) : Permainan bulutangkis merupakan permainan yang bersifat individual, dan dapat dilakukan dengan cara satu orang melawan satu orang, atau dua orang melawan dua orang. Permainan ini menggunakan raket sebagai alat pemukul dan cock sebagai subjek yang dipukul.

Jenis-jenis pukulan yang harus di kuasai oleh seorang pebulutangkis adalah servis, pukulan lob, dropshot, smash, netting, underhand, dan drive. pukulan smash adalah pukulan untuk mematikan bola lawan dan lebih efektif jika disertai dengan lompatan, pukulan ini disebut jump smash. Dengan jump smash maka pukulan smash akan lebih keras dan cepat karena ayunan tubuh dikeluarkan lebih besar hingga shuttlecock jatuhnya lebih keras dan cepat. Kelemahan pukulan ini pebulutangkis akan lebih mudah terasa lelah. Penelitian ini bermula dari observasi yang dilakukan peneliti untuk latihan jump smash yang dilakukan atlet-atlet klub PB Angsapura yang berada di Gedung Olahraga Yayasan Sosial Angsapura yang terletak di jalan Arief Rahman Hakim kota Medan pada bulan November hingga Desember 2019. Saat observasi berlangsung diperoleh fakta bahwa latihan dilakukan dengan disiplin. Sebelum atlet dilatih kemampuan tekniknya terlebih dahulu melakukan pemanasan yaitu lari. Atlet diberikan latihan secara bergantian oleh pelatih. Kemudian peneliti melihat latihan ditambah dengan games setelah latihan teknik. Setiap atlet memperoleh kesempatan bermain dimana lawannya ditentukan oleh pelatih. Peneliti juga melihat saat game berlangsung pukulan para atlet masih kurang kuat sehingga pukulannya lemah saat melakukan jump smash.

Peneliti melakukan pengambilan data awal (pretest) kepada 8 orang atlet pemula yang berumur 10 hingga 15 tahun untuk mengetahui kemampun power setiap atlet. Tes yang dilakukan peneliti antara lain : medicine ball bertujuan untuk mengukur daya ledak otot lengan menurut Imran Akhmad (2013:173), vertical jump bertujuan untuk mengukur daya ledak otot tungkai vertikal menurut Imran Akhmad (2013:171) smash test bertujuan untuk mengukur tingkat kemampuan dan ketetapan testee di dalam melakukan smash menurut Sapta Kunta Purnama (2010:36). Jadi untuk mencapai kemampuan jump smash pada atlet PB Angsapura, salah satu faktor kemungkinan yang berpengaruh terhadap kemampuan jump smash para atlet adalah power otot lengan dan power otot tungkai yang dapat dijadikan obyek dalam penelitian ini. Maka harus diberikan program latihan khusus yang berkaitan untuk melatih power otot lengan dan power otot tungkai untuk meningkatan hasil jump smash atlet PB Angsapura Oleh karena itu, peneliti tertarik untuk menarik penelitian dengan judul "Kontribusi Latihan Knee Tuck Jump Dan Wall Push Up Terhadap Hasil Jump Smash Pada Cabang Olahrga Bulu tangkis Klub PB Angsapura Medan Tahun 2020".

\section{METODE}

Tempat penelitian dilaksanakan di PB Angsapura Medan yang bertepatan di Gedung Olahraga Yayasan Sosial Angspura yang terletak di jalan Arief Rahman Hakim kota Medan. Waktu penelitian dilaksanakan pada tanggal 16 November sampai 28 Desember 2020. Selama 6 (enam) minggu dengan frekuensi latihan 3 (tiga) kali seminggu, pada hari Senin, Rabu dan Jum'at. Populasi ialah yang terdiri atas objek dan subjek yang mempunyai karakteristik yang ditetapkan peneliti untuk dapat dipelajari dan disimpulkan Menurut Arikunto (2006: 101). Populasi dalam penelitian ini ialah Atlet Pb.Angsapura medan yang berjumlah 8 orang. Sesuai 
dengan masalah yang diatas dan tujuan penelitian diuraikan sebelumnya, bahwa penelitian yang dilakukan bertujuan untuk menemukan imformasi kontribusi latihan Knee Tuck Jump dan Wall Push Up terhadap hasil jump smash pada cabang olahraga bulutangkis klub PB Angsapura Medan.

Berhubungan dengan hal tersebut, maka penulisan ini menggunakan metode yang sesuai dengan masalah yang akan diteliti yaitu dengan menggunakan metode eksperimen dengan tehnik pengumpulan data dan pengukuran. Sebelum itu terlebih dahulu sampel di ambil dari data awal (pre-test) yang bertujuan untuk mengetahui kemampuan dari sampel tersebut. Dalam penelitian ini ada 2 (dua) variabel yang akan diteliti yaitu : latihan knee tuck jump dan wall push up sebagai variabel bebas, dan kemudian hasil jump smash bulutangkis sebagai variabel terikat. Desain penelitian yang digunakan adalah pre-test and post-test. Penelitian dilakukan selama 18 kali pertemuan (6 minggu) dengan latihan 3 kali seminggu. Dimana pada awal diambil data pretest kemudian diberi perlakuan dan akhirnya diambil data post-test. Analisis data adalah proses penyederhanaan data ke dalam bentuk yang lebih mudah dibaca dan diinterprestasikan (Singarimbun \& Effendi, 1989 : 263). Untuk menganalisis data hasil survey dan teknik tes pengukuran yang terdiri dari dua variabel bebas dan satu variabel terikat yaitu power otot tungkai (X1) dan power otot lengan (X2) jump smash (Y) digunakan teknik analisis regresi. Sebelum melakukan uji analisis dengan rumus regresi, terlebih dahulu dilakukan sejumlah uji pesyaratan untuk mengetahui kelayakan data meliputi uji normalitas dengan rumus uji liliefors dan uji lineritas data dengan rumus varian.

\section{HASIL \& PEMBAHASAN}

Untuk mencapai tujuan penelitian yang berjudul kontribusi latihan knee tuck jump dengan latihan wall push up terhadap kemampuan hasil jump smash pada cabang olahraga bulutangkis klub PB Angsapura Medan Tahun 2020, maka dilakukan pengumpulan data. Hasil penelitian yang disajikan pada bab ini memuat tentang deskripsi data, pengujian persyaratan analisis dan pengujian hipotesis.

Tabel 1. Data Pre-Test dan Post-Test

\begin{tabular}{|c|c|c|c|c|c|c|c|c|c|}
\hline No & Nama & $\begin{array}{l}\text { Vertical } \\
\text { Jump }\end{array}$ & $\begin{array}{c}\text { Medicine } \\
\text { Ball }\end{array}$ & $\begin{array}{l}\text { Hasil Jump } \\
\text { Smash }\end{array}$ & No & Nama & $\begin{array}{l}\text { Vertical } \\
\text { Jump }\end{array}$ & $\begin{array}{c}\text { Medicine } \\
\text { Ball }\end{array}$ & $\begin{array}{l}\text { Hasil Jump } \\
\text { Smash }\end{array}$ \\
\hline 1 & Habibi & 50 & 52 & 17 & 1 & Habibi & 54 & 52 & 17 \\
\hline 2 & Dafa & 62 & 63 & 15 & 2 & Dafa & 66 & 64 & 18 \\
\hline 3 & Owen & 42 & 41 & 11 & 3 & Owen & 46 & 39 & 13 \\
\hline 4 & Nazir & 45 & 42 & 10 & 4 & Nazir & 43 & 43 & 14 \\
\hline 5 & Arsya & 45 & 44 & 13 & 5 & Arsya & 52 & 49 & 16 \\
\hline 6 & Rehan & 68 & 61 & 16 & 6 & Rehan & 52 & 64 & 17 \\
\hline 7 & Rafli & 50 & 59 & 15 & 7 & Rafli & 55 & 52 & 19 \\
\hline \multirow[t]{5}{*}{8} & Fauzan & 39 & 38 & 10 & 8 & $\begin{array}{c}\text { Fauzan } \\
\Sigma\end{array}$ & 32 & 37 & 13 \\
\hline & $\Sigma$ & 401 & 400 & 107 & & $\bar{X}$ & 400 & 399 & 127 \\
\hline & $\bar{X}$ & & & & & S & & & \\
\hline & & 50,12 & 50 & 13,37 & & & 50,00 & 50,00 & 15,88 \\
\hline & & & & & & & 9,96 & 10,28 & 2,30 \\
\hline
\end{tabular}


Setelah data pre-est dan post-test diperoleh maka langkah selanjutnya adalah menguji hipotesis dengan menggunakan analisis regresi, perhitungan hipotesis dengan langkah-langkah sebagai berikut:

$$
J K(G)=\sum\left\{\sum Y_{k}^{2}-\frac{\sum Y_{k}^{2}}{n_{k}}\right\}
$$

Berdasarkan hasil perhitungan $F_{\text {hitung }}=13,06$ dan $F_{\text {tabel(0.05;1/6) }}=2,36$, sehingga $F_{\text {hitung }}>F_{\text {tabel }}$ maka dapat disimpulkan bahwa model persamaan regresi signifikan. Berdasarkan hasil perhitungan $\mathrm{F}_{\text {hitung }}=11,85$ dan $\mathrm{F}_{\text {tabel(0.05;1/6) }}=2,36$, sehingga $\mathrm{F}_{\text {hitung }}>\mathrm{F}_{\text {tabel }}$ maka dapat disimpulkan bahwa model persamaan regresi signifikan.

$$
\mathrm{F}_{\text {tabel }(0,05 ; 2 / 5)}=5,78 . \mathrm{F}_{\text {hitung }}>\mathrm{F}_{\text {tabel }}=\mathrm{H}_{0} \text { ditolak; Koefisien Korelasi Ganda Signifikan }
$$

Dari hasil perhitungan pada table di atas diperoleh $\mathrm{L}_{0}=0,183$. Pada taraf $\alpha=0.05$ diperoleh $\mathrm{L}_{\text {tabel }}=0,285$. Dengan demikian $\mathrm{L}_{0}=0,183<\mathrm{L}_{\text {tabel }}=0,285$, berarti $\mathrm{H}_{0}$ diterima. Kesimpulannya adalah sampel berasal dari populasi yang berdistribusi Normal.

Dari hasil pengujian hipotesis pertama, dapat dijelaskan bahwa terdapat kontribusi yang signifikan dari latihan knee tuck jump terhadap peningkatan hasil jump smash pada cabang olahraga bulutangkis klub PB Angsapura Medan Tahun 2020, Berdasarkan hasil perhitungan latihan knee tuck jump terhadap hasil jump smash adalah $\mathrm{F}_{\text {hitung }}=13,06$ dan $\mathrm{F}_{\text {tabel(0.05;1/6) }}=2,36$, sehingga $F_{\text {hitung }}>F_{\text {tabel }}$ maka dapat disimpulkan bahwa model persamaan regresi signifikan.

Dari hasil pengujian hipotesis kedua, dapat dijelaskan bahwa terdapat kontribusi yang signifikan dari latihan wall push up terhadap peningkatan hasil jump smash pada cabang olahraga bulutangkis klub PB Angsapura Medan Tahun 2020, Berdasarkan hasil perhitungan latihan wall push up terhadap hasil jump smash adalah $\mathrm{F}_{\text {hitung }}=11,85$ dan $\mathrm{F}_{\text {tabel }(0.05 ; 1 / 6)}=2,36$, sehingga $\mathrm{F}_{\text {hitung }}$ $>\mathrm{F}_{\text {tabel }}$ maka dapat disimpulkan bahwa model persamaan regresi signifikan. Dari hasil hipotesis ketiga menunjukkan bahwa terdapat kontribusi yang signifikan secara bersama-sama dari latihan knee tuck jump dan latihan wall push up terhadap peningkatan hasil jump smash pada cabang olahraga bulutangkis klub PB Angsapura Medan Tahun 2020, Setelah dilakukan perhitungan terhadap latihan Knee Tuck Jump dan latihan Wall Push Up terhadap jump smash di peroleh hasil $\mathrm{F}_{\text {hitung }}=7,2$ dan $\mathrm{F}_{\text {tabel }}=5,78, \mathrm{~F}_{\text {hitung }}>\mathrm{F}_{\text {tabel }}$ maka dapat disimpulkan persamaan regresi ganda signifikan.

\section{SIMPULAN}

Berdasarkan hasil pengujian hipotesis dan pembahasan hasil penelitian, maka peneliti mengambil kesimpulan dimana terdapat kontribusi yang signifikan dari latihan knee tuck jump terhadap peningkatan kemampuan hasil jump smash pada cabang olahraga bulutangkis klub PB Angsapura Medan Tahun 2020, terdapat kontribusi yang signifikan dari latihan wall push up terhadap peningkatan kemampuan hasil jump smash pada cabang olahraga bulutangkis klub PB Angsapura Medan Tahun 2020, serta terdapat kontribusi yang signifikan secara bersama-sama dari latihan knee tuck jump dan wall push up terhadap peningkatan kemampuan hasil jump smash pada cabang olahraga bulutangkis klub PB Angsapura Medan Tahun 2020.

\section{DAFTAR PUSTAKA}

Akhmad, Imran. (2013). Dasar-Dasar Melatih Fisik Olahragawan. Medan: Unimed Press.

Bayu Akbar Harmono. (2013). Kontribusi Konsentrasi Terhadap Ketepatan Pukulan Jumping Smash Pada Bulutangkis. Jurnal Kesehatan Olahraga, 2 (1)

Bompa, O. Tudor. (1983). Theoy and methodologi of Training. Dubuguque: lowa Kendal/Hunt Publishing Company. 
Gusti Pramudeka Gustaman. (2019). Hubungan Footwork, Kekuatan Otot Tungkai Dan Tinggi Lompatan Terhadap Kemampuan Smash Bulutangkis. Jurnal Olahraga.

Harsono. (1988). Coaching dan Aspek-Aspek Psikologi dalam Choaching. Jakarta : Departemen Pendidikan dan Kebudayaan.

Deni Rahman Marpaung (dkk). (2019). Pengaruh Latihan Double Leg Bound Dan Knee Tuck Jump Terhadap Kemampuan Smash Jumping. Jurnal Ilmiah Ilmu Keolahragaan, 3 (2)

Hendya Alif Junanda (dkk). (2016). Kecepatan Dan Akurasi Shuttlecock Pada Jump Smash Dengan Loncatan Vertikal Dan Parabol Depan Dalam Bulutangkis. Jurnal Terapan Ilmu Keolahragaan, 1 (1), 7-23

Heri Yogo Prayadi, Hari Amirullah Rachman. (2013). Pengaruh Metode Latihan Dan Power Lengan Terhadap Kemampuan Smash Bulutangkis. Jurnal Universitas Negeri Yogyakarta

Ismi Thasilatun Nimah \& Mateus Deli. (2017). Buku Pintar Bulutangkis. Jakarta: Perpustakaan Nasional RI.

Nanang Kusnadi. (2015). Kontribusi Fleksibilitas Pergelangan Tangan Dan Power Otot Lengan terhadap Hasil Pukulan smash Dalam Permainan Bulutangkis. Jurnal Multilateral, 14 (2)

Oce Wiriawan. (2016). Kontribusi Kekuatan Otot Lengan, Otot Perut, Otot Kaki, Dan Power Kaki Terhadap Jumping Smash Pada Bulutangkis. Jurnal Universitas Negeri Surabaya

Rezki Ridha Kusuma. (2017). Kontribusi Power Tungkai Dan Power Lengan Terhadap Kemampuan Jumping Smash Badminton Pada Siswa Peserta Ekstrakurikuler SDN 01 Simpangan Cikarang Utara. Jurnal Genta Mulia, 8 (2)

Ryan Marvino Augusta \& Mochammad Purnomo. (2015). Hubungan Antara Tinggi Badan, Berat Badan, Kekuatan Otot Perut, Kekuatan Otot Lengan, Kelentukan Pergelangan Tangan, Kekuatan Otot Tungkai Dan Power Kaki Terhadap Hasil Jumping Smash. Jurnal Universitas Negeri Surabaya

Sapta Kunta Purnama. (2010). Kepelatihan Bulutangkis Modern. Surakarta: Yuma Pustaka. 